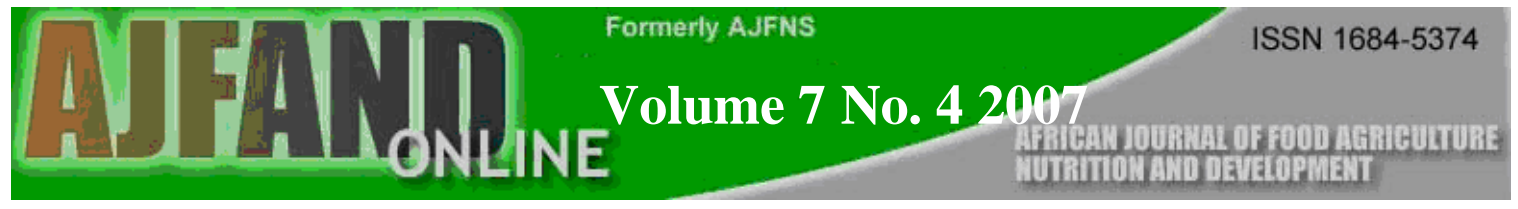

\title{
Marketing African Leafy Vegetables: Challenges and Opportunities in the Kenyan Context
}

\section{By}

\author{
Kennedy M. Shiundu*1 and Ruth. K. Oniang'o ${ }^{2}$
}
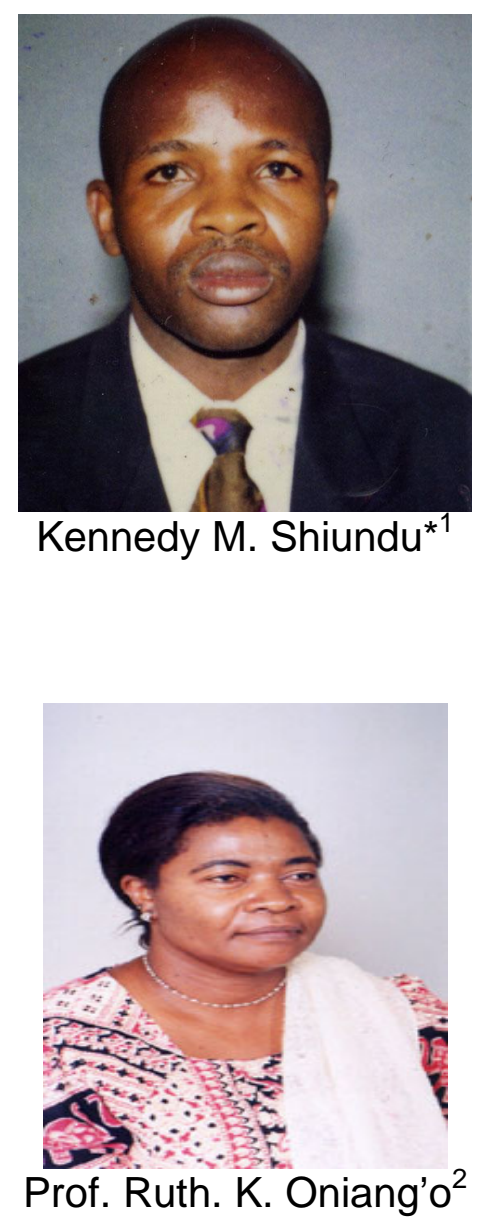

${ }^{*}$ Corresponding author Email- kmshiundu@yahoo.co.uk

${ }^{1}$ P.O BOX 9682-00100, Nairobi, Kenya

${ }^{2}$ Executive Director, Rural Outreach Program, P.O BOX 29086-00625 Nairobi, Kenya. Email- oniango@iconnect.co.ke 


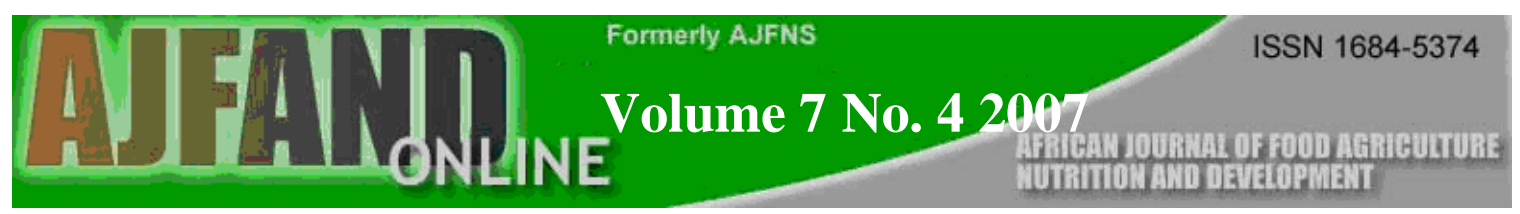

\section{ABSTRACT}

Activities to scale up production and consumption of African leafy vegetables have increased greatly in the recent past. What are the emerging issues in relationship to commercialization of these vegetables, given their previous unexploited state? The market share of ALVs vis-à-vis other vegetable species, particularly kales, cabbages and spinach, has been on the upward trend, in the urban markets and increased consumption in rural areas too. How has this influenced the various players in the ALVs sector for example farmers, traders and consumers? Issues of quality control, reliability and pricing remain critical to the future success of ALVs farming. The fact that ALVs are fast becoming the vegetable of choice, especially in the hitherto, non-consuming segments of the society including the upper and middle class households, and generally among the elite in Kenya is a situation that requires serious assessment and action plan. The paradigm shift in the consumption patterns of ALVs has implications on the continued availability of the vegetables to the lower-end of the market consumers-the poor. Therefore, the reality that their income and nutritional resources could be exploited to their disadvantage is very much a possibility. What should be the policy and research considerations in the unfolding scenario? Women have been closely associated with cultivation and selling of ALVs; however, studies have shown that whenever a crop begins to appreciate in the market and starts fetching higher income, men tend to push their way into the trade. Similarly, higher income prospects in any trade create competition and sooner or later non-competitive segments of the market fall by the way side in due course, and in our case these would be small-scale farmers and traders. These issues are fundamental and need focusing as ALVs enter a new phase of production and consumption regimes. More efforts are needed to cushion the vulnerable groups, who have previously dominated the ALVs market, against the emerging big and medium commercial players. Otherwise, exploitation and loss of livelihoods among the vulnerable groups will be inevitable.

Key words: African Leafy Vegetables, Women, Commercialization. 


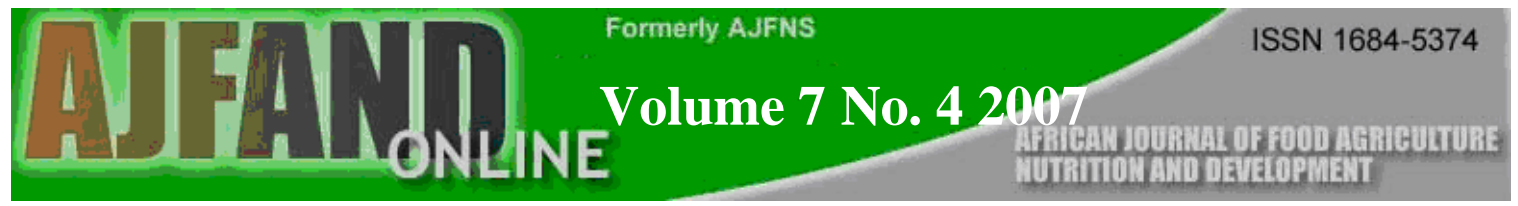

\section{INTRODUCTION}

Humanity derives most of its food, many medicines and industrial products from both wild and domesticated components of plant genetic resources. However, the reduction of this biodiversity has been an inevitable consequence of human development as species-rich forests and wetlands are converted to relatively species-poor farmlands and plantations [1].

\section{The diversity of plant species}

It has been estimated that there are between 300,0000 and 500,0000 species of higher plants, of which approximately 240,000 have been identified and or described [2]. About 30,000 are edible and about 7,000 have been cultivated or collected by human beings for food at one time or another [3]. Thus several thousand species may be considered to contribute to food security. It is, however, known that only 120 are important on a national scale, as 30 of these crops 'feed the world' and provide $95 \%$ of the dietary energy (calories) or proteins $[4,5]$.

\section{Status of plant genetic resources in Africa}

Plant genetic resources are the biological basis for food security and directly or indirectly support the livelihoods of the rural majority in Africa as they are used as food, medicines, feed for domestic animals and other amenities [6]. Plant genetic resources are the raw materials used in the production of new cultivars either through traditional plant breeding or biotechnology. Whether used directly by farmers as raw materials or plant breeders, these resources are a reservoir of genetic adaptability that acts as a buffer against potentially harmful environmental and economic changes [7].

\section{Genetic erosion and the causes}

The genetic base of Africa's plant diversity is being seriously eroded, largely as a result of a multiplicity of environmental, political and socio-economic factors. The main cause of genetic erosion in crops, as reported by almost all countries signatories to the Global Plan of Action (GPA) on plant genetic resources for food and agriculture is the replacement of local varieties by 'improved' or exotic varieties and species [8]. There are many other causes of this erosion, which has been accelerating throughout the $20^{\text {th }}$ century in parallel with the demands of an ever increasing population and greater competition for natural resources $[9,10]$. 


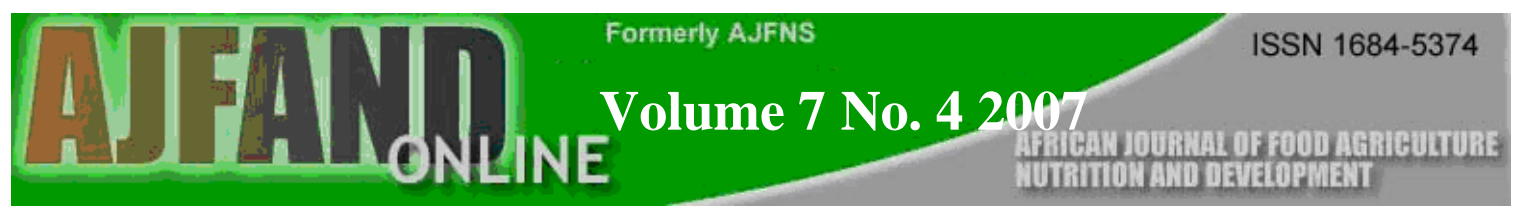

\section{Conservation status}

The impetus for conservation has been inspired by several recent global initiatives such as the Convention on Biological Diversity, the UNCED and more recently, the Global Plan of Action. Traditionally the conservation of genetic resources has primarily been through ex situ conservation [11-13]. However, there is increased realization that this method is not adequate for conservation of the various gene pools due to increased and diversified user demands and requirements. The CBD and the Global Plan of Action have specifically called for both in situ and ex situ conservation measures for biodiversity and genetic resources conservation $[14,15]$.

The decision on the choice (s) of the conservation methods is not only a matter of available technology and resources but it is also influenced by biological, economical, management, socio-economic, cultural and political considerations $[16,17]$. The objective of ex situ conservation of genetic resources is the collection, maintenance and regeneration of the genetic variation of a gene pool ensuring its existence and availability in the long term. The concept demands that collection methods initially capture maximum variation and subsequently conservation and regeneration techniques minimize losses through time [18].

For in situ conservation, the objective of conservation is to maintain viable breeding populations in their natural habitats and for crops, in land use systems and cultural heritages in which they have continually evolved and are adopted to $[7,6]$.

Lately in situ conservation has included the continued cultivation and maintenance of land races by farmers 'on farm' is such as in the areas they have continued to evolve and have developed their distinctive properties [19, 20]. This offers the possibility of providing incentives to local farmers to act as custodians of traditional varieties and selections nurtured in their fields and backyards [21]. In this case the cultural integrity of the local peoples and the conservation of the genetic resources are closely linked [22].

\section{African Leafy Vegetables in sub-Saharan Africa}

It is estimated that there are more than 45,000 species of plants in sub-Saharan Africa of which about 1000 can be eaten as green leafy vegetables. This group of vegetables, which researchers fondly refer to as "African spinach", a kind of short-hand for hundreds of green leafy vegetables, happen to be the mainstay of traditional African diets. Eaten largely in rural areas, African spinach provides millions of African consumers with the vitamins and minerals needed to maintain health and fight off infections. 


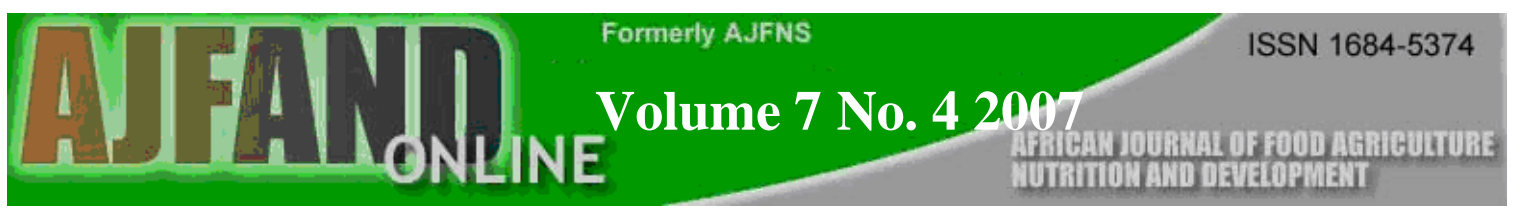

Included are crops with names such as Garden Rocket, Cats Whiskers and Garden Huckleberry [23].

Today, access to food around the world is not secure [24]. Eight hundred million people are undernourished while 200 million children under 5 years of age are underweight. In the next 30 years, the world's population is expected to grow by over 2,500 million to reach 8, 500 billion. Reliable and sustainable improvements in yield will be needed to meet the demands of this growing population. The conservation and sustainable utilization of plant genetic resources are key to improving agricultural productivity and sustainability, thereby contributing to national development, food security and the alleviation of poverty.

Per capita consumption of fruit and vegetable in sub-Saharan Africa lags behind that of the other regions, showing an overall decline between 1986 and 1995. While per capita apparent consumption of vegetables in developing countries went from $68.7 \mathrm{~kg}$ per capita in 1986 to $75.3 \mathrm{~kg}$ in 1995 on average (a $0.92 \%$ increase), Sub-Saharan Africa showed a $0.19 \%$ decline and remained as low as $29 \mathrm{~kg}$ of vegetables per capita consumption on average [25].

It is therefore, no wonder that micronutrient deficiency (mainly vitamins and minerals particularly iron, selenium, folate, copper, zinc, iodine and vitamin A) is a serious problem in SSA - affecting about a third of the population and with far reaching effects. It is the major cause of anemia, impaired intellectual development in thousands of children and affects the immune system, provoking birth defects and debilitating economic prospects of countries [26].

It is ironic that as Africa grapples with malnutrition, the continent is endowed with a high diversity of underutilized fruits, and vegetables that are rich in micronutrients [27]. It is in this regard that in 2001, International Plant Genetic Resource Institute (IPGRI) - with support from International Development Research Centre of Canada-has been spearheading a major public awareness campaign including training of farmers to grow leafy vegetables in hygienic conditions and has worked with a marketing expert in Kenya to attract new customers for ALVs. A local NGO, Family Concern, distributes the farmers' produce to Kenya's largest supermarket chain [27].

According to the results of a survey done in Cameroon, Yaoundé by International Institute of Tropical Agriculture (IITA) team of scientists, it was interesting to find that often, overlooked traditional leafy vegetables are essential for both nutrition and economic livelihood. The scientists reported that in and around Yaoundé, traditional vegetables were not only more important than Brassica spp. for household food consumption and income generation, they were also among the most commonly found vegetables in home gardens of the poorest households [28]. 


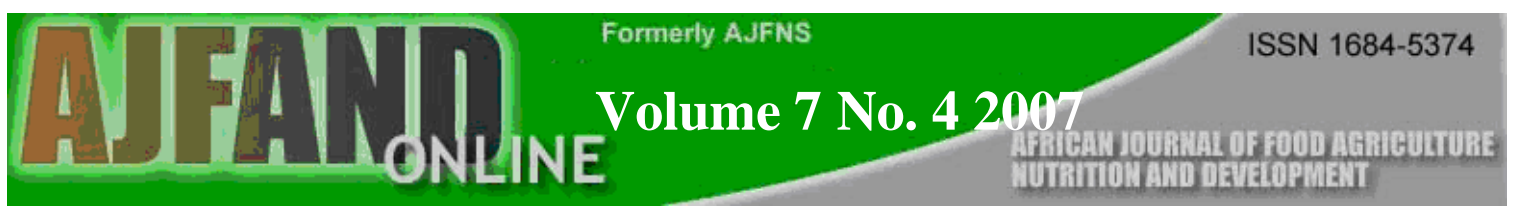

\section{AFRICAN LEAFY VEGETABLES AND NUTRIENT BIOAVAILABILITY}

African leafy vegetables represent one of the richest sources of biodiversity in African food systems and a potential rich source of beta-carotene [29]. However, the poor bioavailability of provitamin $\mathrm{A}$ in a number of studies has called into question the importance of these accessible, acceptable foods in the diets of local African communities [30]. Nonetheless, many of the benefits of nonnutrients in ALVs may exceed those attributable to the beta-carotene or other nutrients.

For example, vegetable diets that make modest contributions to improving vitamin A status result in significant increases in serum levels of lutein, antioxidant xanthophylls which offers protective benefits in relation to ocular disease, as well as cardiovascular disease and cancer, are increasingly recognized as of importance to health $[30,31]$. Such insights have potential significance in tropical countries where cataracts represent the major cause of blindness [32]. In one study it was shown that Nigerian patients with cataracts had lower intake of fruits and vegetables than control subjects [33]. Compilations of data on xanthophylls point to the richness of the ALVs in these non-nutrient carotenoids; extension of these analyses to indigenous plant foods is needed $[34,35]$. In light of this important functional activity (and undoubtedly others), the single-minded attention on the limitation of ALVs and other plant foods as sources, for example of a single nutrient such as provitamin A seems somewhat shortsighted [30].

\section{INTERNATIONAL PLANT GENETIC RESOURCES INSTITUTE (IPGRI) PROJECT IN AFRICA}

Sub-Saharan Africa is the region with the highest percentage of undernourished people in the total population. It was estimated that about $34 \%$ of the population were undernourished in 1997-99. It is the only developing region in the world where agricultural output has been trailing population growth for most of the last three decades [36]. The reasons for Africa's inability to feed itself with sufficient quantity and quality food are numerous and varied and include conflicts, diseases such as malaria and HIV/AIDS, poor-performing economies, poor governance and policies, inadequate technology and technology transfer mechanisms, lack of access to foods that are nutritionally rich in vitamins and minerals and inability to make full use of the easily accessible traditional foods.

International Plant Genetic Resource Institute (IPGRI now Bioversity) has been involved with promotion of African Leafy Vegetables (ALVs) in sub-Saharan Africa (SSA) since 1995 [23]. 


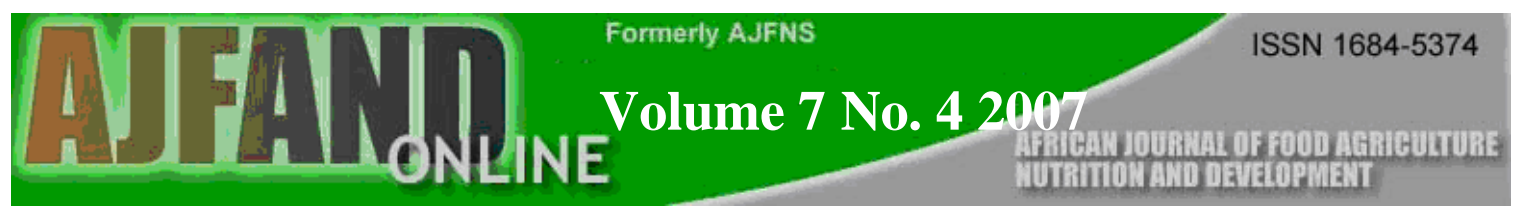

IPGRI, in partnership with the Dutch government, has led a campaign to try and reverse the decline in use of ALVs.

They have managed to document the ALVs species and identified the key issues hindering their cultivation, conservation and marketing. About 210 species were recorded in Kenya alone. Yet only about 10 of these found their way to markets, usually back-street markets frequented by a small number of regular customers [23].

Subsequently, in the second phase of the campaign which began in 2001, the project has supported a variety of activities and projects including collecting and analyzing samples of the most widely used leafy vegetables, such as amaranth, African nightshades, and cowpea.

\section{COLLABORATION OF IPGRI AND LOCAL NGOS TO PROMOTE ALVS}

\section{THE OUTCOMES OF THE AFRICAN LEAFY VEGETABLE PROJECT}

The rapid acceptance of these vegetables among the socially elite in Kenya means that the ALVs production is now becoming a potentially profitable venture and will soon no longer be a simple women's crop, meant only to supplement the family diet. Men could take up the trade in view of their increasing demand, as they have also become main consumers of ALVs. Evidence is emerging that ALVs are now a much sought-after item on menus of back-street eating venues, in the five-star hotels and are now served, even in Parliament.

The project has managed to improve farmers' livelihoods in project areas by providing them with high quality seeds and market opportunities in the formal and informal markets. Sections of consumers now have better access to the vegetables and this is bound to affect their nutrition and health status positively.

Marketing is a major constraint in the use of ALVs and often the missing link. In Kenya, this has partially been solved by training farmers on quality seeds and linking them to the formal market. The appearance of ALVs in supermarkets for example, has given the vegetable status.

This success story needs to be scaled-up to other towns in Kenya and other countries. Consumers also need more nutritional information and recipes. The little information available has proved very useful in promotional campaigns and has been in high demand. Important as urban and peri-urban vegetable production may be, it still poses major challenges particularly of hygiene and heavy metal contamination and therefore, the need for more thoughtful solutions. 


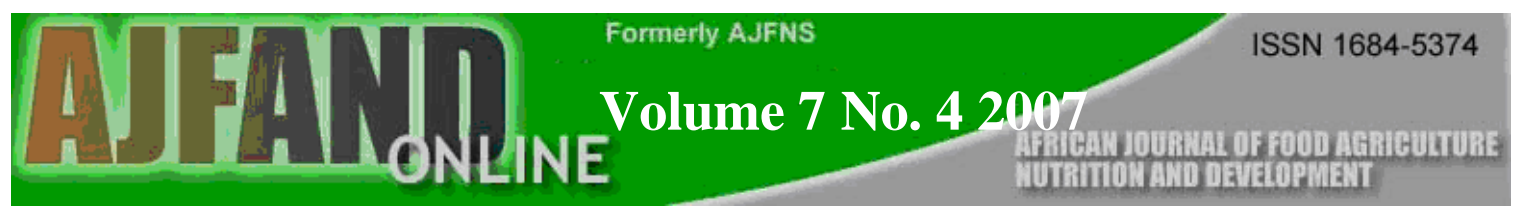

The reported successes in terms of rising levels of demand for ALVs have a flip side to it. The fact that the vegetables are increasingly perceived as lucrative means that many well-heeled players are joining the fray, but the most worrying aspect of this trend is the continual marginalization of the small-scale players, both farmers and traders alike.

Women have played a key role in the past in conserving ALVs through cultivation and consumption in rural areas.

This might soon be a thing of the past, as the ALVs assume a more commercial outlook, and men increasingly get involved in their production and marketing. The possibility of both women and small-scale players losing out in what was once their traditional source of livelihood cannot be gainsaid. Almost inevitably, the propensity of ALVs playing a role in alleviation of poverty and malnutrition among the poor may significantly reduce.

This is aptly captured by what has happened in Uganda regarding traditional vegetables. In Uganda traditional vegetables have been commercialized including species such as 'Malakwang' (Hibiscus spp), 'Nakati' (Solanum gilo), 'Katunkanna' (Solanum indicum subsp.Disticum), 'Doodo' (Amaranthus dubious), and 'Bbugga' (Amaranthus lividus) particularly around the city of Kampala and in other urban areas. It is instructive to note that now; it is mainly the men who cultivate them. Middlemen purchase these vegetables from the farmers (men) and transport them to the markets and in the market women buy them and retail to the general public [37]. Indeed here, women have ceased to be farmers and now they can only be contended with retail trade component of the traditional vegetables.

\section{MOBILIZATION OF WOMEN FARMERS BY RURAL OUTREACH PROGRAMME}

Rural Outreach Programme (ROP) is a non-profit organization based in Kenya. Since 1997, ROP has been working with farmers of Butere Division in rural western Kenya to grow African leafy vegetables and to produce seed for marketing with an overall intention of alleviating poverty and improving nutrition among the resource-poor farmers of this predominantly sugar-cane growing area. ROP works mostly with women groups.

There are over 200 women groups, with a total membership of about 5000 people. ROP recognized the marginal position women occupy in this community, and therefore, primarily initiated the ALVs project as a way of addressing food and nutrition security, income generation and women's empowerment, factors whose negative effects on overall well-being of the community are pronounced.

Published by Rural Outreach Program
KARI-NARL Complex, Westlands, off Walyaki Way
P.O. Box 29086-00625 TEL; +254-20-4444030 FAX: $+254-20-4444030$
Nairobi, KENYA
Email: oniango@iconnect.co.ke OR info@ajfand.net www.ropkenya.org




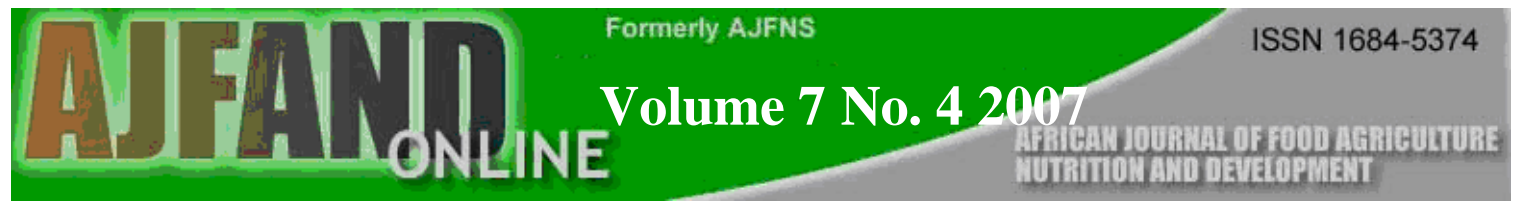

ALV is probably the only crop today in the western part of Kenya, which provides a practical chance for women to earn income. Why? Because, this being a predominantly sugar-cane growing zone, the main cash crop- sugarcane, is dominated by men. The deterioration in the socio-economic status of most households in this area has been attributed to this marginalization of women when it comes to planning and use of sugarcane proceeds.

Studies have found that introduction of cash crop farming is not necessarily beneficial to food and nutrition security in some communities. Kennedy and Cogill found that a shift from maize (food crop) to sugar cane (cash crop farming) resulted in higher incomes but the nutritional status of preschoolers did not change [38].

ROP started with a modest coverage, serving one sub-location of Butere Division in western Kenya. The area of focus has since expanded to cover much of Butere-Mumias District. About 5000 farmers affiliated to ROP now supply vegetables and seeds to other farmers in the rest of the district, which has a population of about 540,000 people. The farmers also supply seeds and vegetables to major cities like Kisumu and Nairobi. This is now a major source of income for the farmers.

Selected trained farmers grow vegetables for seeds. Seeds are sold to a local 'seed bank' managed by ROP. On average, the bank receives about $40 \mathrm{Kg}$ of seed per month from the farmers. In 2001, ROP opened a distribution point in Nairobi, the capital city where farmers from all over the country (small scale as well as commercial) could access the seeds.

Since 2002, ROP farmers have been supplying African leafy vegetable seeds to farmers in peri-urban part of Nairobi and surrounding rural areas. Today, the bulk of the vegetable that is supplied by farmers to the formal sector in Nairobi is supported by seed material from Butere farmers working with ROP. The linkage with Nairobi market has succeeded because of the facilitation done by Family Concern Inc. a local NGO.

Women in Butere-Mumias district, particularly in Butere and Khwisero divisions are among the pioneers of ALVs trade in Kenyan urban centers. The main reason why the cultivation and marketing of the vegetables thrived was due to cheap rail transport that links Butere to major urban areas of Kisumu, Nairobi and Mombasa. With time and as the business became lucrative, men joined, often as middlemen. Middlemen buy the vegetables in bulk from women farmers at very low prices, and then transport them in passenger trains to Nairobi and other parts of the country. 


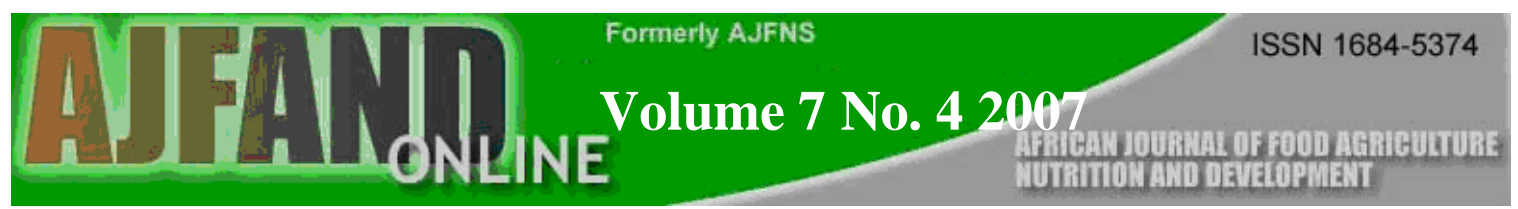

In the mid 1990's, the rail services to Butere from Kisumu, the nearest city, were suspended due to economic reasons. This almost ruined the once-thriving ALVs business in the area, which by the time of suspension stood at over 2 tones of trainload per day. The main destination was urban markets of Kisumu and Nairobi. In the absence of the rail transport, most traders resorted to local markets and others opted for buses. But this option proved quite expensive and so the majority of traders went out of business.

Almost a decade later in 2004, the railway services resumed and quickly the ALVs business was back on track but on a smaller footing because the service was only available two to three times a week. In early 2005, the railways managing agency, Kenya Railways Corporation banned the use of passenger cabins from transporting any agricultural products including ALVs on its ButereNairobi train-passenger-services. Instead, passengers were supposed to use the luggage cabins. Traders using the luggage cabins suffered heavy losses due to poor aeration in the cabins leading to rapid deterioration of the vegetable. It is now difficult to use the train and farmers and traders have again turned to the more expensive means - the buses. The traders have now formed some form of cooperatives that transport the vegetables in bulk and also negotiate lower transport costs with local bus companies.

\section{CHALLENGES EMANATING FROM INCREASED UTILIZATION OF ALVS IN ADDRESSING NUTRITION AND INCOME GENERATION OF RESOURCE- POOR FARMERS}

\section{Seasonal production}

Like the rest of agricultural activities in Kenya, ALVs farming relies mostly on rain-fed agriculture. Consequently, this leads to fluctuating supply of ALVs on the markets. The outcome of this is pronounced in the remote parts of the country where production takes place. Because most small-scale farmers lack means to transport their produce to far-distant and lucrative markets in the urban centers, they are open to exploitation by middlemen. This can be addressed through value adding processes, particularly solar drying and proper packaging.

\section{Research}

Researches focusing on improving the productivity of ALVs are few and far apart, not converging to a meaningful consensus of issues. But this has improved tremendously in the past four years or so. It is also worth noting that in the absence of clear policy on these vegetables, there is a lot of duplication of activities by organizations. 


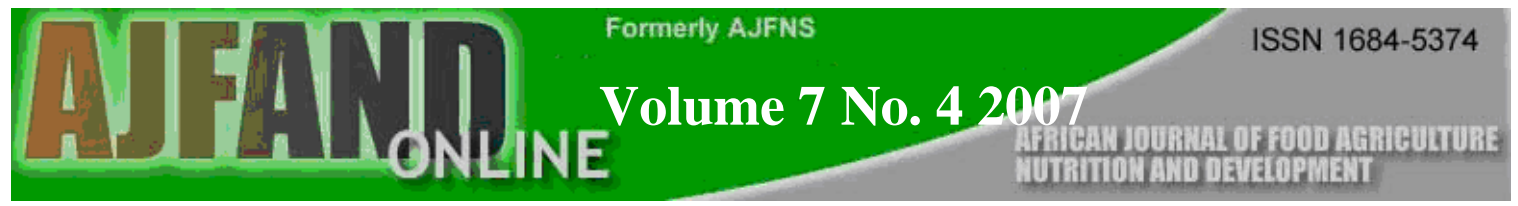

All these contribute to continual low production and negligible improvement in the income of resource-poor farmers whose dependence on this activity is particularly critical.

\section{Physical infrastructure}

The poor state of infrastructure, particularly roads, that is found in most of the rural areas where ALVs are cultivated worsens during the rainy season. There is much wastage because of unavailability or limited means of transport to reach the markets at such time. Even those vegetables that manage to get to the markets are poor in quality due to delay and subsequent biological deterioration during transportation and distribution processes.

\section{Diversity in production and cross consumption}

The nature of ALVs is that each community tends to have a number of species, which they have been exploiting over many years or even centuries. In this regard, some species are only consumed in particular parts of the country. This in a way limits the marketability of some species across the communities, regions, across generations and even gender.

\section{POSSIBLE OPPORTUNITIES EMANATING FROM INCREASED UTILIZATION OF ALV IN ADDRESSING NUTRITION AND INCOME GENERATION OF RESOURCE-POOR FARMERS}

\section{Irrigation}

Reliance on rain-fed agriculture in production of ALVs has been one of the major obstacles in expanding their production. There is always overproduction of the vegetables in the rainy season and this obviously depresses their prices, and inturn occasioning great loses to farmers and traders. Use of irrigation to produce ALVs during dry season is extremely useful in optimizing farmers' returns when the supply is low in the market. Similarly, irrigation production ensures continued supply, which ensures stability in the prices of vegetables in the market and enabling even the low-income groups to access them.

\section{Co-operative structures}

In areas where ALVs is a major economic activity like Kisii region and western province, there have been efforts to mobilize farmers to form groups. The level of organization is still basic. The farmers need to work together in order to have a strong voice and a united position as they negotiate for favorable prices for their produce. 


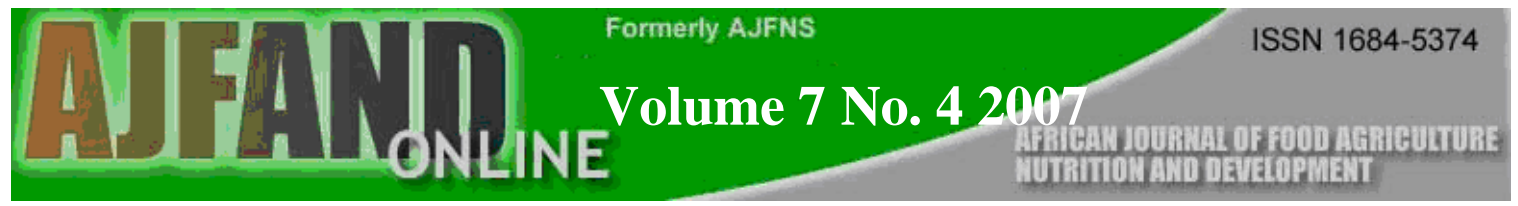

It is even much easier to transport in bulk if farmers agree on the logistics hence avoid falling victims to the middlemen. This approach may also reduce the transactional cost for farm inputs and aggregate demand for services such as training and advisory services.

\section{Export market}

There are possibilities to consider exporting the vegetables. Kenyans in diaspora would relish identifying themselves with the vegetables. The Asian vegetables are a major component of the Kenya's horticultural industry, because of the people of Asian origin who reside in United Kingdom and other parts of Europe. The possibility of exporting ALVs to Africans, East Africans or Kenyans living abroad, is worth investigating for possible action.

\section{Capacity building in marketing and business skills}

Public education and promotion of ALVs needs to support the marketing component. Farmers need to be taken through marketing and business skills to enable them maximize output as well as income from their farms. This can be done through workshops and seminars. Farmers can also have exchange-visit programmes to familiarize with marketing concepts, especially those that work.

\section{Use by public institutions}

Many public institutions are yet to incorporate the indigenous vegetables - in the wider context, traditional foods- in their dietary systems. Boarding schools and colleges, prisons and hospitals have an opportunity to vary and improve their dietary contents with the highly nutritious indigenous vegetables. Few institutions use these vegetables, and where they do, it is very occasional.

\section{Research and extension}

It is generally agreed that the future of ALVs is dependent on increased research on nutrition and crop genetics, and to improve seed storage facilities, processing and marketing [39]. It is not enough to encourage local farmers to grow their traditional crops. Successful marketing is important in the effort of creating sustainable livelihoods.

The issue of toxicity is very important hence the need to develop and apply standard scientific methods to evaluate the nutritional and toxic properties of the ALVs. Further, it is critical to educate the public on the nutritive values of ALVs and possible associated toxicity. This will promote user confidence and increase vegetable consumption [40]. 


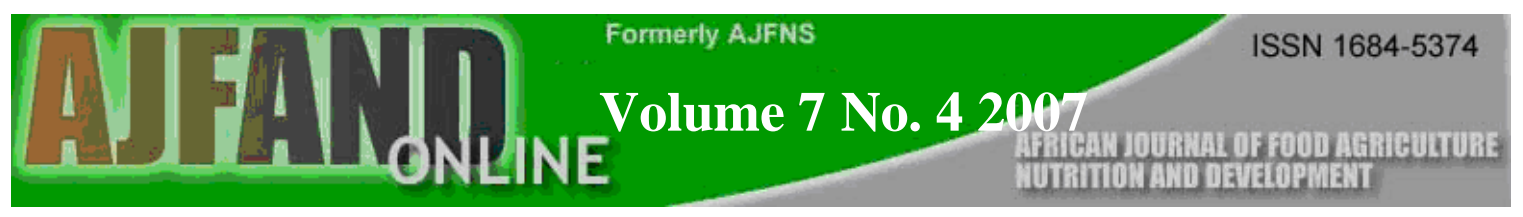

\section{CONCLUSION}

There are many odds against the accelerated growth of ALVs trade, yet at the same time the wave of goodwill going around the world through poverty reduction strategies focusing on biodiversity and underutilized species, gives indigenous vegetable a unique opportunity to make a lasting impact in the area of food and nutrition security, especially for the millions of vulnerable and resource-poor households in Africa.

Getting neglected crops back on the menu is important, but it is also important to ensure that the poor get a fair share of any commercial benefits that arise from exploiting these genetic resources. 


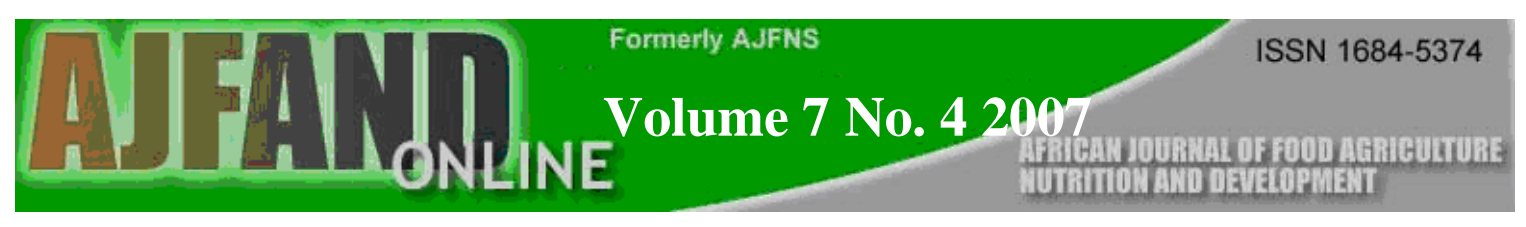

\section{REFERENCES}

1. Kiambi D and K Attah-Krah Plant Genetic Resources. In: GH Schmelzer and EA Omino (Eds). Proceedings of the I PROTA International Workshop. 23-25 September 2002 Nairobi Kenya. PROTA Foundation, Wageningen, the Netherlands. 2003: 33-52.

2. Heywood VH (Ed) Global Biodiversity Assessment. UNEP, Cambridge University Press, Cambridge, UK. 1995.

3. Wilson EO The Diversity of Life. Penguin, London, UK. 1992.

4. McNeely JA and PS Watchtel The Soul of Tiger. Doubleday, New York, USA. 1988.

5. Mooney PR The Law of Seed. Development Dialogue. 1983; 1-2: 1-172.

6. FAO. Plant Genetic Resources: Their Conservation in situ for Human Use. Rome, Italy. 1989.

7. Hoyt EL Conserving the Wild Relatives of Crops. IBPGR/IUCN/WWF. 1988

8. FAO. The State of the World's Plant Genetic Resources for Food and Agriculture. Rome, Italy. 1998.

9. ITDG. IPRs, Access and Benefit Sharing. 2001. http://www.ukabc.org.

10.ITDG. Sustaining Agricultural Biodiversity: Genetic, Species, Ecosystems, Cultural and Temporal Dimensions. 2001.

11. De Langhe EAI The Role of in vitro Techniques in Germplasm Conservation. In: Holden JHW and JT Williams (Eds) Crop Genetic Resources: Conservation and Evaluation. George Allen and Unwin, London, UK. 1984.

12. Ford-Lloyd $\mathbf{B}$ and $\mathbf{M}$ Jackson Plant Genetic Resources: An Introduction to their Conservation and Use. Edward Arnold Publishers, London, UK. 1986.

13. King MW and EH Roberts Maintenance of Recalcitrant Crop Seeds. In: HF Chin and EH Roberts (Eds). Recalcitrant Crop Seeds. Tropical Press, Kuala Lumpur, Malaysia. 1980.

14. FAO. The Global Plan of Action on Plant Genetic Resources for Food and Agriculture. Rome, Italy. 1998. 


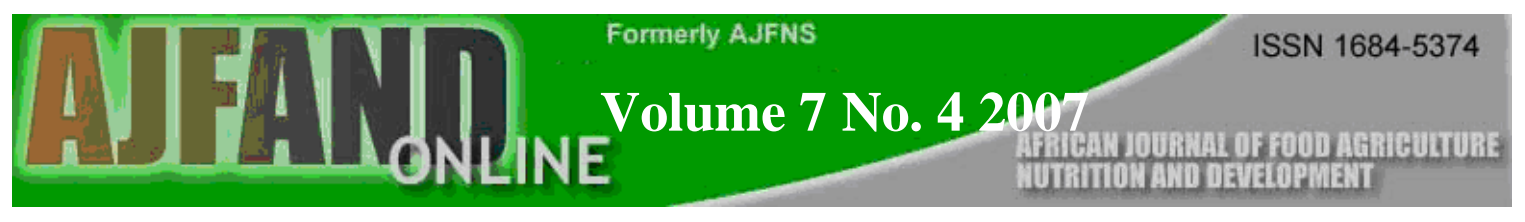

15. UNEP. Convention on Biological Diversity. Nairobi, Kenya. 1992.

16. Astley D Preservation of Genetic Diversity and Accession Integrity. Field Crops Research. 1992; 29: 205-224.

17. Frankel $\mathrm{OH}$ and $\mathrm{ME}$ Soule Conservation and Evaluation. Cambridge University Press, Cambridge, UK. 1981.

18.FAO/IBPGR. Report of the Expert Consultation on Gene Bank Standards, 2629 May 1992. Rome, Italy. 1992.

19. Brush SB In situ Conservation of Landraces in Centres of Crop Diversity. Crop Science. 1995; 35: 346-354.

20. Maxted N, Ford-Lloyd BV and JG Hawkes (Eds) Plant Genetic Conservation. The in situ Approach. Chapman and Hall, London, UK. 1997.

21. Atieri MA and LC Merrick In situ Conservation of Crop Genetic Resources through Maintenance of Traditional Farming Systems. Economic Botany. 1997; 41: 86-96.

22. Smith NJH, Williams JT, Plucknett DL and JP Talbot Tropical Forests and their Crops. Cornell University Press, Ithaca, USA. 1992.

23. IPGRI. With Time Running out, Scientists Attempt Rescue of African Vegetables Crops. International Plant Genetic Resource Institute, Rome, Italy. 2004. http://www.futureharvest.org.

24. MacCalla AF Agriculture and Food Need to 2025: Why We Should be Concerned. Sir John Crawford Memorial Lecture, CGIAR International Centres Week, 27 October 1994, Washington DC, USA. 1994.

25. Segrè $\mathbf{A}$, Brandani $\mathbf{A}$ and $\mathbf{F}$ Lunati The World Tables on Fruit and Vegetables Development. Summaries. Prepared for WCHR-WG1. 1998.

26. UNICEF. Report on Vitamin and Mineral Deficiency in Sub-Saharan Africa. 2004.

27. Oniang'o RK, Shiundu MK, Maundu $\mathbf{P}$ and $\mathbf{T}$ Johns African Leafy Vegetables: Efforts to Change a Traditionally Subsistence Crop into a Major Driver in Poverty Alleviation and Improvement of Health in sub-Saharan Africa. International Consultation on the Value of Bio-diversity in Achieving the UN Millennium Development Goal of Freedom from Hunger and Poverty. Chennai, India. 2005. 


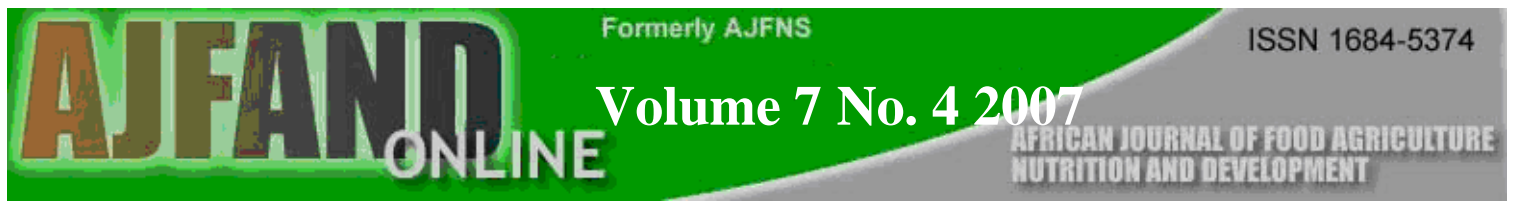

28. Gockwski J, Mbazo's J, Mbah G and TF Moulende African 'Traditional Leafy Vegetables and the Urban and Peri-urban Poor'. International Institute of Tropical Agriculture (IITA). Yaoundé. 2003. http://www.scienceinafrica.

29. Chweya JA and PB Eyzanguire (Eds) International Plant Genetic Resource Institute (IPGRI). Rome, Italy.1999.

30. de Pee S, West CW, Permaesih D, Martuti S, Muhilal JG and AJ Hautvast Orange Fruit is more effective Than Dark-Green Leafy Vegetables in Increasing Serum Concentrations of Retinol and Beta-Carotene in School children in Indonesia. Amer. J. Clin. Nutr. 1998; 68: 1058-1067.

31. Mares-PerIman JA, Millen AE, Ficek TL and SE Hankinson The Body of Evidence to Support a Protective Role for Lutein and Xeaxanthin in Delaying Chronic Disease. Overview. J. Nutr. 2002; 132: 518S-524S.

32. Lewallen $\mathbf{S}$ and $\mathbf{P}$ Courtright Blindness in Africa: Present Situation and Future Needs. Brit. J. Ophthalmol. 2001; 85: 897-903.

33. Ojofeitimi EO, Adelekan DA, Adeoye A, Ogungbe TG, Imoru AO and EC Oduah Dietary and Lifestyle Patterns in the Aetiology of Cataracts in Nigeria Patients. Nutr. Health .1999; 13: 61-68.

34. Holden JM Carotenoid Content of U. S. Foods: An Update of the Database. J. Food Composit. Anal. 1999; 12: 169-196.

35. O'Neill ME, Carrol Y, Corridan B, Olmedilla B, Granado F, Blanco I, Van den Berg H, Hininger I, Rousell AM, Chopra M, Southon S and DI Thurnham A European Carotenoid Database to Assess Carotenoid Intake and it's Use in a Five-Country Comparative Study. Brit. J. Nutr. 2001; 85: 499-507.

36. FAO. Food, Agriculture and Food Security: Developments since the World Food Conference and Prospects. World Food Summit Technical Background Document 1. World Food Summit Technical Background documents, Vol. 1. Rome, Italy. 1996.

37. Rubaihayo EB The Contribution of Indigenous Vegetables to Household Food Security. 2002. http:// www.worldbank.org.

38. Kennedy E and B Cogill Income and Nutritional Effects of the Commercialization of Agriculture in Southwestern Kenya. IFPRI Reports 63. Washington, DC.1987. 


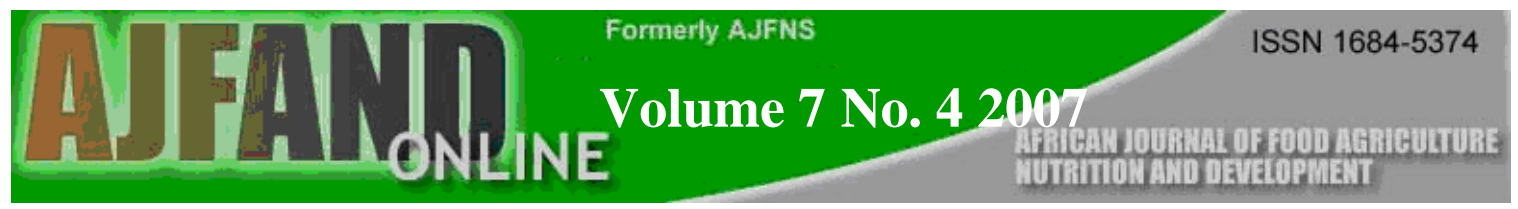

39. Padma TV Beating World Hunger: The Return of 'Neglected' Crops. 2005. http://www.scidev.net.

40. Orech FO, Akenga T, Ochora J, Friis $\mathbf{H}$ and $\mathbf{J}$ AagardHansen Potential Toxicity of Some Traditional Leafy Vegetables Consumed in Nyang'oma Division, western Kenya. Africa Journal of Food and Nutritional Sciences. Vol. 5. No. 1. 2005. http://www.ajfandnet. 